\title{
PENERAPAN METODE DEKOMPOSISI BLINDER-OAXACA UNTUK MENGANALISIS KESENJANGAN UPAH ANTAR GENDER DI PROVINSI KALIMANTAN TIMUR TAHUN 2018 \\ Maura Lovieta Jean Laurensia ${ }^{1}$, Lia Yuliana² \\ ${ }^{1}$ Politeknik Statistika STIS \\ ${ }^{2}$ Politeknik Statistika STIS \\ E-mail: 111709819@stis.ac.id
}

\begin{abstract}
ABSTRAK
Pemerintah telah mengupayakan berbagai program responsif gender demi mewujudkan tujuan SDG's ke-5 yakni kesetaraan gender. Namun, perempuan masih menghadapi kesenjangan khususnya di sektor ketenagakerjaan salah satunya adalah kesenjangan upah. BPS mencatat perbedaan upah antara pekerja perempuan dan laki-laki di Kalimantan Timur pada tahun 2018 berada pada peringkat 6 nasional. Oleh sebab itu, penelitian ini akan menginvestigasi kesenjangan upah antar gender di Kalimantan Timur dengan menggunakan data Sakernas Agustus 2018. Data dianalisis dengan menerapkan regresi robust untuk mengestimasi upah pekerja secara terpisah untuk masing-masing gender. Robust digunakan untuk mengatasi pelanggaran asumsi normalitas dan homoscedasitas pada model OLS sebagai akibat adanya pencilan. Selanjutnya, hasil estimasi upah digunakan sebagai dasar dekomposisi Blinder-Oaxaca dalam mengukur kesenjangan upah antar gender dan mendekomposisikan penyebabnya menjadi perbedaan karakteristik yang dapat diobservasi (explained) dan faktor yang tidak dapat diobservasi (unexplained). Penulis menemukan status perkawinan, pendidikan, pelatihan, jam kerja, status kegiatan, serikat pekerja, lapangan usaha, dan jenis pekerjaan berpengaruh terhadap upah pekerja baik perempuan ataupun laki-laki. Perbedaan model upah kedua gender adalah upah pekerja perempuan juga dipengaruhi oleh pengalaman kerja sementara laki-laki dipengaruhi oleh status dalam rumah tangga. Hasil dekomposisi menyatakan pekerja perempuan menerima upah 36,59 persen lebih rendah dibandingkan laki-laki. Dari total kesenjangan upah, 46,49 persen disebabkan perbedaan karakteristik dan 53,51 persen disebabkan faktor unexplained. Kesenjangan upah antar gender dapat ditekan dengan memperluas akses dan kesempatan perempuan untuk menempuh pendidikan tinggi, terlibat dalam sektor formal, dan menduduki jabatan menengah-tinggi (kerah putih), serta mengeliminasi diskriminasi terhadap perempuan dalam pasar tenaga kerja
\end{abstract}

Kata kunci: Kesenjangan, upah, gender, robust, Blinder-Oaxaca

\begin{abstract}
The Government has endeavored various gender responsive program to realize the $5^{\text {th }}$ SDG's - gender equality. However, women still face gender gap especially in employment sector, one of those is gender wage gap. BPS notes that wages difference between male and female workers in Kalimantan Timur Province in 2018 is ranked $6^{\text {th }}$ nationally. Therefore, this study aims to investigate the gender wage gap in Kalimantan Timur Province by using Agustus 2018 Sakernas data. The data were analyzed by applying robust regression to estimate worker wages separately for each gender. Robust is used to overcome the violation of normality and homoscedasticity in OLS model as a result of outliers. Then, the wage estimation results are used as the basis of Blinder-Oaxaca decomposition in measuring the gender wage gap and decompose the causes into differences in characteristics that can be observed (explained) and factors that cannot be observed (unexplained). We found that marital status, education, training, working hours, formal-informal sector, trade union, industrial, and occupation affect both female and male worker's wage. The difference between female and male wage is that the female worker's wage are also influenced by work experience while male are affected by status in the household. Decomposition result show female worker received 36,59 percent less than male workers. Difference in characteristics contribute 46,49 percent of the total wage gap while unexplained factor contribute 53,51 percent. The gender wage gap can be reduced by expanding women's
\end{abstract}


access and opportunities to pursue higher education, work in formal sector, hold middle-high positions (collar worker), and eliminate discrimination against women in labour market.

Keywords: Gender, wage, gap, robust, Blinder-Oaxaca

\section{PENDAHULUAN}

Sustainable Develeopment Goals (SDG's) pada agenda ke-5 mensyaratkan setiap negara untuk mewujudkan kesetaraan gender dan memberdayakan semua perempuan. Namun, meski pemerintah telah menetapkan kebijakan dan menjalankan program pembangunan yang responsif gender, perempuan masih menghadapi tantangan keterbatasan akses dan diskriminasi di berbagai sektor tak terkecuali ketenagakerjaan, salah satunya adalah persoalan kesenjangan upah. Menurut International Labour Organization (2016) kesenjangan upah berdasarkan gender merupakan kondisi di mana rata-rata upah perempuan relatif lebih kecil dibandingkan laki-laki. Kesenjangan upah antar gender dapat diukur melalui nilai perbedaan upah, yaitu selisih rata-rata upah laki-laki dan perempuan terhadap rata-rata upah laki-laki. Berdasarkan laporan BPS, pada tahun 2018, perbedaan upah di Indonesia sebesar 24,05 persen. Artinya pekerja perempuan Indonesia menerima rata-rata upah 24,05 persen lebih rendah dibandingkan laki-laki.

Fenomena kesenjangan upah antar gender berlaku di seluruh wilayah Indonesia, tak terkecuali Kalimantan Timur. Bahkan kesenjangan upah antar gender di Kalimantan Timur tercatat berada pada peringkat 3 pada tahun 2016 dengan nilai perbedaan upah sebesar 35,91 persen, peringkat 2 pada tahun 2017 dengan nilai perbedaan upah sebesar 31,28 persen, dan peringkat 6 pada tahun 2018 dengan perbedaan upah sebesar 27,39 persen. Kesenjangan upah antar gender di Kalimantan Timur menarik untuk diteliti sebab Kalimantan Timur tercatat sebagai salah satu provinsi yang makmur di Indonesia. Hal ini diidentifikasi melalui PDRB per kapita Kalimantan Timur yang berada pada peringkat 1 dari tahun 2010-2013 dan peringkat 2 dari tahun 2014-2018. Menurut Widayanti et al. (2013) semakin maju atau makmur suatu negara yang ditandai dengan Gross Domestic Product (GDP) per capita yang tinggi maka tingkat kesenjangan upah antar gender semakin rendah. Namun hal demikian tidak berlaku di Kalimantan Timur. Hal ini mengindikasikan adanya subordinasi peran perempuan dalam roda perekonomian Kalimantan Timur.

Perlu digarisbawahi bahwa penggunaan perbedaan upah untuk mengukur kesenjangan upah antar gender memiliki keterbatasan. Perbedaan upah yang merupakan perbandingan sederhana antara upah perempuan dan laki-laki mengabaikan faktor penting, seperti perbedaan karakteristik antara perempuan dan laki-laki serta bias atau diskriminasi dalam pasar tenaga kerja (Chamberlain, 2016). Merujuk pada penelitian Jacobsen (1974), kesenjangan upah disebabkan investasi modal manusia seperti pendidikan, pelatihan, dan pengalaman kerja perempuan umumnya lebih rendah dibandingkan laki-laki. Selain itu, preferensi perempuan dalam memilih jenis pekerjaan dan menentukan jam kerja juga dapat menyebabkan kesenjangan upah antar gender. Perempuan cenderung memilih jenis pekerjaan yang nyaman dan tidak berisiko seperti perawat dan guru dan memilih untuk bekerja dengan jam kerja yang fleksibel agar dapat memenuhi tanggung jawab mengurus rumah tangga (Hennigusnia, 2014). Mardiana (2015) menambahkan bahwa stereotype majikan yang menganggap produktivitas perempuan lebih rendah dibandingkan laki-laki juga bertanggung jawab dalam menyebabkan kesenjangan upah antar gender. 
Oleh karena itu Blinder (1973) dan Oaxaca (1973) mengembangkan suatu metode untuk mengukur kesenjangan upah antar gender serta mendekomposisikan penyebabnya menjadi perbedaan karakteristik antara perempuan dan laki-laki yang dapat diobservasi (explained) seperti perbedaan capaian pendidikan, tempat bekerja, jam kerja dan jenis pekerjaan serta faktor yang tidak dapat diamati (unexplained). Nilai unexplained mengindikasikan adanya diskriminasi pengupahan terhadap perempuan. Metode ini lazim disebut metode dekomposisi Blinder-Oaxaca.

Oleh sebab itu, penelitian akan menerapkan metode dekomposisi Blinder-Oaxaca dalam menganalisis kesenjangan upah antar gender di Kalimantan Timur Tahun 2018. Dalam rangka mencapai tujuan tersebut, peneliti akan mengkaji karakteristik pekerja laki-laki dan perempuan di Provinsi Kalimantan Timur serta pengaruh karakteristik tersebut terhadap upah pekerja pada masing-masing gender. Sehingga, selanjutnya dapat diidentifikasi apakah kesenjangan upah antar gender disebabkan perbedaan karakteristik antara perempuan dan laki-laki (explained) atau faktor lain yang tidak dapat dijelaskan (unexplained).

\section{Tinjauan Pustaka}

Dalam mengkaji kesenjangan upah antar gender, penelitian ini mengacu pada teori modal manusia, teori segregasi pekerjaan, dan teori diskriminasi. Teori modal manusia menyatakan bahwa perempuan cenderung memiliki investasi pada modal manusia (pendidikan, pelatihan kerja, dan pengalaman kerja) yang lebih rendah dibandingkan laki-laki sebagai konsekuensi atas tanggung jawab domestik (Polachek, 1981). Kemudian, berkaitan dengan teori segregasi pekerjaan, England (1992) menjelaskan bahwa gagasan sosial yang menitikberatkan tanggung jawab domestik pada perempuan menyebabkan rendahnya perkiraan terhadap kemampuan perempuan dalam bekerja. Konsekuensinya, terjadi pengelompokkan pekerjaan (segregasi pekerjaan) di mana perempuan cenderung terserap di sektor pekerjaan dan posisi dengan upah yang lebih rendah daripada laki-laki. Sementara itu, menurut Polachek (1981) perbedaan upah perempuan dan laki-laki disebabkan perempuan cenderung memilih pekerjaan dengan upah yang lebih rendah untuk dapat memenuhi tanggung jawab domestik. Selanjutnya, teori diskriminasi yang diinisiasi oleh Becker (1971) menjelaskan bahwa pekerja minoritas seperti perempuan menghadapi prasangka yang bersumber dari pengusaha (majikan), rekan kerja, dan konsumen. Dalam kondisi tertentu, prasangka ini dapat mengarah pada perbedaan upah antara perempuan dan laki-laki (Blau \& Kahn, 2017)

Sejumlah penelitian telah dilakukan untuk mengidentifikasi penjelasan konkret mengenai kesenjangan upah antar gender dengan menerapkan metode dekomposisi Blinder-Oaxaca salah satunya adalah penelitian yang dilakukan oleh Mardiana (2015). Mardiana (2015) menemukan besarnya kesenjangan penghasilan antar gender yang terjadi di Indonesia pada tahun 2013 adalah sebesar 47,29 persen. Di mana hanya 12,47 persen disebabkan oleh faktor endowment atau explained (umur, tingkat pendidikan, tempat tinggal, status kegiatan, jenis pekerjaan, lapangan usaha, dan jam kerja), sementara 87,53 persen lainnya disebabkan oleh faktor diskriminasi. Dalam menganalisis kesenjangan upah antar gender, penelitian ini akan memperkaya variabel bebas sehingga diharapkan dapat diperoleh hasil yang lebih sesuai dengan kebenaran. Penelitian ini juga akan menggunakan data Sakernas yang lebih baru dan membatasi konsentrasi wilayah penelitian hanya pada Provinsi Kalimantan Timur.

Berdasarkan uraian teori dan penelitian terkait mengenai kesenjangan upah antar gender, maka diperoleh kerangka pikir sebagai berikut: upah individu dipengaruhi oleh karakteristik sosial demografi (daerah tempat tinggal, status perkawinan, dan status dalam rumah tangga), karakteristik modal manusia (pendidikan, pelatihan, pengalaman kerja), dan karakteristik pekerjaan (jam kerja, status kegiatan, serikat pekerja, lapangan usaha, dan jenis pekerjaan). Perbedaan karakteristik antara perempuan dan laki-laki (explained) dapat berkontribusi dalam menciptakan kesenjangan upah antar gender. Di samping itu, kesenjangan upah antar gender 
diduga disebabkan oleh berbagai faktor lain yang tidak dapat dijelaskan (unexplained). Faktor unexplained mengindikasikan adanya diskriminasi terhadap perempuan di dalam pasar tenaga kerja.

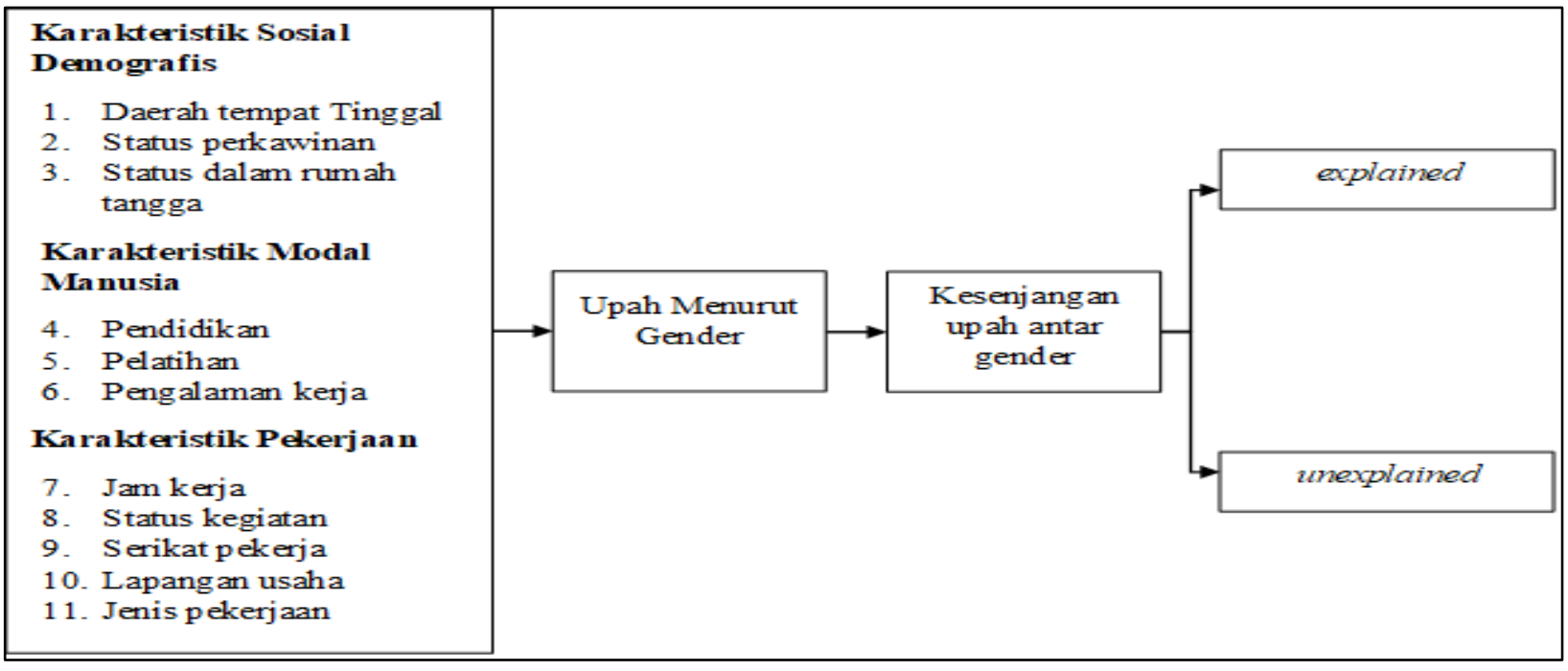

Gambar 1. Kerangka pikir

\section{METODE}

Penelitian ini menggunakan data Survei Angkatan Kerja Nasional (Sakernas) bulan Agustus 2013 Provinsi Kalimantan Timur. Unit Analisis dalam penelitian ini mencakup pekerja atau penerima upah, yaitu penduduk yang bekerja dengan status pekerjaan utama sebagai pekerja bebas pertanian, pekerja bebas non pertanian, dan buruh/karyawan/pegawai. Dari sampel Sakernas Agustus 2018 Kalimantan Timur didapatkan 2934 pekerja yang terdiri dari 2134 laki-laki dan 860 perempuan. Tabel 1 menjabarkan definisi operasional variabel terikat dan variabel bebas yang digunakan dalam penelitian ini.

Tabel 1. Definisi Operasional.

\begin{tabular}{|c|c|c|c|}
\hline No. & Variabel & Definisi Operasional & Kategori \\
\hline 1 & Upah & $\begin{array}{l}\text { Penghasilan bersih atau upah/gaji pokok dan } \\
\text { tunjangan yang diterima pekerja }\end{array}$ & Numerik \\
\hline 2 & $\begin{array}{l}\text { Daerah tempat } \\
\text { tinggal }\end{array}$ & $\begin{array}{l}\text { Pengklasifikasian tempat tinggal penduduk } \\
\text { berdasarkan kondisi geografisnya }\end{array}$ & $\begin{array}{l}\text { Perkotaan } \\
\text { Perdesaan (acuan) }\end{array}$ \\
\hline 3 & $\begin{array}{l}\text { Status } \\
\text { Perkawinan }\end{array}$ & $\begin{array}{l}\text { Status perkawinan dibedakan berdasarkan } \\
\text { status perkawinan pada saat pencacahan }\end{array}$ & $\begin{array}{l}\text { Kawin } \\
\text { Tidak kawin (acuan) }\end{array}$ \\
\hline 4 & $\begin{array}{l}\text { Status dalam } \\
\text { rumah tangga }\end{array}$ & $\begin{array}{l}\text { Variabel ini mengidentifikasi apakah individu } \\
\text { berkedudukan sebagai kepala rumah tangga } \\
\text { atau bukan }\end{array}$ & $\begin{array}{l}\text { KRT } \\
\text { Bukan KRT (acuan) }\end{array}$ \\
\hline 5 & Pendidikan & $\begin{array}{l}\text { Jenjang pendidikan tertinggi yang berhasil } \\
\text { ditamatkan }\end{array}$ & $\begin{array}{l}\text { SMP ke bawah (acuan) } \\
\text { SMA sederajat } \\
\text { Pendidikan tinggi }\end{array}$ \\
\hline 6 & Pelatihan & $\begin{array}{l}\text { Kegiatan yang memberikan suatu keterampilan } \\
\text { atau keahlian tertentu dan memperoleh tanda } \\
\text { lulus/sertifikat }\end{array}$ & $\begin{array}{l}\text { Mengikuti pelatihan } \\
\text { Tidak mengikuti pelatihan } \\
\text { (acuan) }\end{array}$ \\
\hline 7 & $\begin{array}{l}\text { Pengalaman } \\
\text { kerja }\end{array}$ & $\begin{array}{l}\text { Pengalaman kerja (potensial) }=\text { umur }- \text { tahun } \\
\text { pendidikan }-6\end{array}$ & Numerik \\
\hline 8 & Jam kerja & $\begin{array}{l}\text { lama waktu yang digunakan untuk bekerja } \\
\text { pada pekerjaan utama }\end{array}$ & Numerik \\
\hline
\end{tabular}




\begin{tabular}{|c|c|c|}
\hline Status kegiatan & $\begin{array}{l}\text { Status kegiatan dari pekerjaan individu yang } \\
\text { ditetapkan berdasarkan status pekerjaan }\end{array}$ & $\begin{array}{l}\text { Formal } \\
\text { Informal (acuan) }\end{array}$ \\
\hline Serikat pekerja & $\begin{array}{l}\text { Keikutsertaan pada organisasi pekerja yang } \\
\text { memperjuangkan hak pekerja }\end{array}$ & $\begin{array}{l}\text { Ikut serikat pekerja } \\
\text { Tidak ikut serikat pekerja } \\
\text { (acuan) }\end{array}$ \\
\hline Lapangan usaha & $\begin{array}{l}\text { bidang kegiatan dari pekerjaan/usaha/ } \\
\text { perusahaan/kantor tempat seseorang bekerja }\end{array}$ & $\begin{array}{l}\text { Pertanian } \\
\text { Industri Manufaktur } \\
\text { Pelayanan dan jasa (acuan) }\end{array}$ \\
\hline Jenis Pekerjaan & $\begin{array}{l}\text { Macam pekerjaan yang dilakukan oleh } \\
\text { seseorang yang dikategorikan berdasarkan } \\
\text { status sosial pekerja }\end{array}$ & $\begin{array}{l}\text { TNI dan POLRI } \\
\text { Kerah putih } \\
\text { Kerah biru (acuan) }\end{array}$ \\
\hline
\end{tabular}

Metode analisis yang digunakan dalam penelitian ini adalah analisis deskriptif dan analisis inferensia. Analisis deskriptif digunakan untuk memberikan gambaran umum mengenai perbedaan karakteristik pekerja perempuan dan laki-laki Kalimantan Timur. Analisis inferensia dalam penelitian ini menerapkan metode dekomposisi Blinder-Oaxaca dengan alur analisis sebagai berikut: analisis diawali dengan estimasi upah pekerja secara terpisah untuk masing-masing gender dengan metode Ordinary Least Square. Selanjutnya, menerapkan regresi robust dengan metode estimasi method of moment (robust MM) untuk mengatasi pelanggaran asumsi normalitas dan homoscedasitas akibat adanya pencilan. Hasil estimasi upah digunakan sebagai dasar dekomposisi Blinder-Oaxaca dalam mengukur kesenjangan upah antar gender dan menghitung kontribusi faktor perbedaan karakteristik (explained) dan faktor lain yang tidak diamati (unexplained).

\section{Robust MM}

Robust merupakan teknik statistika yang dikembangkan untuk menyediakan hasil regresi yang resisten terhadap kehadiran pencilan. Salah satu metode estimasi pada regresi robust adalah metode estimasi method of moment (MM). Metode ini menggabungkan sifat high breakdown point (50\%) pada estimasi S dan efisiensi yang tinggi pada estimasi M. Bentuk dari metode estimasi MM adalah:

$\hat{\beta}_{m m}=\sum_{i=1}^{n} x_{i j} \rho_{1}^{\prime}\left(u_{i}\right)=\sum_{i=1}^{n} x_{i j} \rho_{1}^{\prime}\left(\frac{e_{i}}{\widehat{\sigma}_{s}}\right)=0$

dengan $\rho_{1}^{\prime}$ adalah turunan dari $\rho, e_{i}$ adalah residual yang diperoleh dari regresi robust dengan estimasi-S, dan $\hat{\sigma}_{s}$ diperoleh dari rumus berikut:

$\hat{\sigma}_{s}=\sqrt{\frac{1}{n(0,199)} \sum_{i=1}^{n} w_{i} e_{i}^{2}}$

Adapun tahapan regresi robust dengan metode estimasi MM diuraikan sebagai berikut (Susanti et al., 2013):

1. Menghitung nilai residual $\left(e_{i}\right)$ dari estimasi-S;

2. Menghitung nilai $\hat{\sigma}_{i}=\hat{\sigma}_{s n}$;

3. Menghitung nilai $u_{i}=\frac{e_{i}}{\widehat{\sigma}_{i}}$;

4. Menghitung nilai $w_{i}$

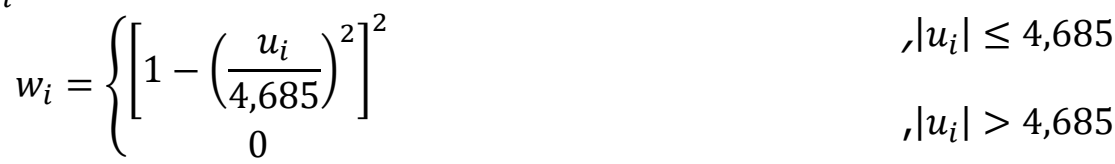

5. Menghitung parameter $b_{M M}$ dengan metode WLS dengan pembobot $w_{i}^{0}$; 
6. Mengulangi langkah b-e sampai diperoleh nilai $b_{M M}$ yang konvergen;

7. Melakukan uji hipotesis (pengujian keberartian model).

\section{Dekomposisi Blinder-Oaxaca}

Estimasi upah umumnya mengikuti persamaan Mincer (1974):

$Y_{i}=\operatorname{Ln} Y_{i}=\beta_{0}+\beta_{1} X_{i 1}+\beta_{2} X_{i 2}+\cdots+\beta_{k} X_{i k}+\varepsilon_{i}$

$Y_{i}=\operatorname{Ln} Y_{i}=\beta_{0}+\sum_{i=1}^{n} \beta_{k} X_{i k}+\varepsilon_{i}$

Estimasi upah untuk masing-masing gender dapat dituliskan dengan persamaan berikut:

$Y_{i}^{L}=\beta_{0}^{L}+\sum_{i=1}^{n} \beta_{k}^{L} X_{i}^{L}+\varepsilon_{i}^{L}$

$Y_{i}^{P}=\beta_{0}^{P}+\sum_{i=1}^{n} \beta_{k}^{P} X_{i}^{P}+\varepsilon_{i}^{P}$

Di mana $\mathrm{L}$ adalah laki-laki dan $\mathrm{P}$ adalah perempuan.

Hasil estimasi upah masing-masing gender dapat dituliskan dengan persamaan berikut: $\bar{Y}^{L}=b^{L} \bar{X}^{L}$

$\bar{Y}^{P}=b^{P} \bar{X}^{P}$

Kesenjangan upah antar gender merupakan total perbedaan dari upah laki-laki dan perempuan, sehingga nilainya ditentukan dengan mengurangi persamaan 7 dan 8 .

$\Delta \bar{Y}=\bar{Y}^{L}-\bar{Y}^{P}=b^{L} \bar{X}^{L}-b^{P} \bar{X}^{P}$

Dalam mendekomposisikan total perbedaan upah, persamaan 9 perlu disesuaikan dengan ratarata upah kontrafaktual. Pada penelitian ini, rata-rata upah kontrakfaktual menggunakan laki-laki sebagai kelompok referensi (male-based decomposition). Metode ini mengasumsikan bahwa lakilaki menerima upah atas produk marginal sementara perempuan menghadapi diskriminasi pengupahan. Rata-rata upah bagi seseorang perempuan akan diwakili oleh:

$C F=$

$b^{L} \bar{X}^{P}$

Setelah disesuaikan dengan rata-rata upah kontrafaktual, maka persamaan kesenjangan upah menjadi:

$$
\begin{aligned}
& \Delta \bar{Y}=\bar{Y}^{L}-\bar{Y}^{P}=\left(b^{L} \bar{X}^{L}-b^{L} \bar{X}^{P}\right)-\left(b^{P} \bar{X}^{P}-b^{L} \bar{X}^{P}\right) \\
& \Delta \bar{Y}=\bar{Y}^{L}-\bar{Y}^{P}=b^{L}\left(\bar{X}^{L}-\bar{X}^{P}\right)+\bar{X}^{P}\left(b^{L}-b^{P}\right) \ldots \ldots \ldots
\end{aligned}
$$

Keterangan:

$b^{L}\left(\bar{X}^{L}-\bar{X}^{P}\right) \quad:$ Perbedaan karakteristik (Explained)

$\bar{X}^{P}\left(b^{L}-b^{P}\right) \quad: \quad$ Unexplained

\section{HASIL DAN PEMBAHASAN}

\section{Gambaran Umum Karakteristik Pekerja}

Tabel 2. Deskripsi Pekerja Menurut Jenis Kelamin dan Karakteristik Provinsi Kalimantan Timur Tahun 2018.

Karakteristik Laki-laki Perempuan

$\begin{array}{clllr}\text { Karakteristik } & \text { Daerah tempat } & \text { Perkotaan } & 69,51 & 76,47 \\ \text { Sosial } & \text { tinggal (\%) } & \text { Perdesaan } & 30,49 & 23,53\end{array}$


Demografis

Karakteristik

Modal Manusia

Karakteristik

Pekerjaan
Total

Kawin

Status perkawinan (\%)

Belum/pernah kawin

Total

KRT

Status dalam rumah tangga (\%)

Pendidikan (\%)

A sederajat

Pendidikan tinggi

Total

Mengikuti pelatihan

Pelatihan (\%)

Tidak mengikuti pelatihan

Total

Pengalaman kerja (rata-rata dalam tahun)

Jam kerja (rata-rata jam kerja biasanya dalam seminggu)

Formal

Status kegiatan (\%) Informal

Total

Serikat Pekerja

Serikat Pekerja (\%) Tidak serikat pekerja

Total

Pertanian

Lapangan usaha

(\%)

Industri Manufaktur

Pelayanan dan Jasa

Total
$100,00 \quad 100,00$

71,56

41,99

28,44

58,01

$100,00 \quad 100,00$

62,18

7,87

37,82

92,13

$100,00 \quad 100,00$

$33,57 \quad 24,12$

$48,73 \quad 37,15$

$17.70 \quad 38,72$

$100,00 \quad 100,00$

$23,10 \quad 21,83$

$76,90 \quad 78,17$

$100,00 \quad 100,00$

$19-17$

$49 \quad 42$

$92,74 \quad 96,34$

$7,26 \quad 3,66$

$100,00 \quad 100,00$

$81,93 \quad 81,17$

$18,07 \quad 18,83$

$100,00 \quad 100,00$

$13,78 \quad 7,40$

$37,08 \quad 8,52$

$49,14 \quad 84,08$

$100,00 \quad 100,00$ 


\begin{tabular}{llrr} 
& TNI dan Polri & 1,35 & 0,06 \\
& Kerah putih & 44,68 & 77,20 \\
Jenis Pekerjaan (\%) & Kerah biru & 53,96 & 22,73 \\
& Total & $\mathbf{1 0 0 , 0 0}$ & $\mathbf{1 0 0 , 0 0}$ \\
Observasi (N) & & 2134 & 860 \\
\hline
\end{tabular}

Gambaran umum mengenai karakteristik pekerja disajikan pada tabel 2. Ditinjau menurut karakteristik sosial demografis, sebagian besar pekerja baik laki-laki ataupun perempuan bertempat tinggal di daerah perkotaan. Hal demikian, menandakan akses pekerja pada pekerjaan layak dan produktif lebih terbuka. Tabel 2 juga memperlihatkan bahwa sebagian besar pekerja laki-laki berstatus kawin sementara perempuan berstatus belum/pernah kawin. Hasil ini membuktikan kecenderungan perempuan untuk meninggalkan pekerjaannya demi memenuhi tanggung jawab di rumah sekaligus kecenderungan perusahaan untuk mempekerjakan perempuan tidak kawin. Sebagian besar pekerja laki-laki berkedudukan sebagai KRT, sebaliknya, hampir seluruh pekerja perempuan berkedudukan sebagai bukan KRT. Akibatnya, pekerjaan perempuan dianggap sekunder dan pelengkap saja sebab perempuan dipandang bergantung secara ekonomi pada KRT (suami atau-ayah) sehingga kompensasi tenaga kerja mereka (upah perempuan) juga pelengkap saja.

Dikaji menurut karakteristik modal manusia, tidak terdapat perbedaan karakteristik pelatihan dan pengalaman kerja yang signifikan antara pekerja laki-laki dan perempuan. Bahkan, persentase pekerja perempuan yang menyelesaikan pendidikan tinggi tercatat lebih besar dibandingkan lakilaki. Hal ini mengindikasikan meluasnya kesempatan bagi perempuan untuk menempuh pendidikan dan mengembangkan modal manusianya. Francis (2007) berargumen peningkatan pendidikan perempuan disebabkan meningkatnya kecenderungan perempuan untuk menunda waktu menikah.

Dilihat dari karakteristik pekerjaan, sebagian besar pekerja baik perempuan ataupun laki-laki merupakan pekerja formal dan tergabung dalam serikat pekerja. Namun, perbedaan cukup nyata ditunjukkan pada karakteristik jam kerja, lapangan usaha dan jenis pekerjaan. Tabel 2 menginformasikan rata-rata jam kerja perempuan lebih rendah dibandingkan laki-laki. Hal ini dikarenakan, perempuan cenderung mengurangi jam kerja demi memenuhi tanggung jawab di rumah. Dari sisi lapangan usaha, tabel 2 menunjukkan pekerja laki-laki tersebar merata di sektor industri manufaktur dan sektor pelayanan dan jasa, sementara perempuan mendominasi sektor pelayanan dan jasa. Grybaite (2006) menjelaskan perempuan diharapkan berpartisipasi pada pekerjaan yang melibatkan kepedulian, pengasuhan, dan pelayanan. Konsekuensinya, perempuan menghadapi pembatasan potensi dan karier seperti minimnya penyerapan perempuan pada sektor pertanian dan industri manufaktur. Berdasarkan jenis pekerjaan, sebagian besar pekerja perempuan merupakan pekerja kerah putih. Hal ini menandakan meluasnya kesempatan perempuan untuk menduduki jabatan menengah hingga tinggi, seperti manajer, profesional, teknisi dan asisten profesional, tenaga tata usaha, dan tenaga usaha jasa dan tenaga penjualan.

\section{Faktor-faktor yang Mempengaruhi Upah Pekerja}

Tabel 3. Ringkasan Pemeriksaan Asumsi

\begin{tabular}{crrrrr} 
No. & Asumsi & Statistik Uji & Laki-laki & Perempuan & Keputusan \\
& & & & \\
\hline 1 & Normalitas & Jarque Bera & $p$-value $=0,000$ & $p$-value $=0,000$ & Terlanggar
\end{tabular}




$\begin{array}{llllll}2 & \text { Homoscedasitas } & \text { Glejser } & p \text {-value }=0,000 & P \text {-value }=0,000 & \text { Terlanggar } \\ 3 & \text { Nonautokorelasi } & \begin{array}{l}\text { Durbin } \\ \text { Watson }\end{array} & 1,786 & 1,846 & \text { Terpenuhi } \\ & \text { VIF } & \begin{array}{l}\text { Semua variabel } \\ \text { bebas memiliki VIF }< \\ 10\end{array} & \begin{array}{l}\text { Semua variabel } \\ \text { bebas memiliki VIF }< \\ 10\end{array} & \text { Terpenuhi }\end{array}$

Berdasarkan hasil pemeriksaan asumsi (disajikan pada tabel 3), terjadi pelanggaran asumsi normalitas dan homoscedasitas pada persamaan upah pekerja kedua gender dengan metode OLS. Hasil pendeteksian pencilan dengan cook's distance mendapati 108 observasi laki-laki dan 51 observasi perempuan yang termasuk amatan berpengaruh. Keberadaan amatan berpengaruh dapat mendistorsi persamaan regresi dan menyebabkan pelanggaran asumsi. Untuk mengatasi permasalahan tersebut, peneliti menerapkan regresi robust dengan metode estimasi MM. Namun, perlu menjadi catatan bahwa regresi robust belum mengatasi pelanggaran asumsi homoscedasitas sehingga estimator bersifat inefisien. Meski demikian, hasil estimasi tetap bersifat unbias sehingga masih valid untuk digunakan dalam analisis. Adapun persamaan regresi robust untuk kedua gender adalah sebagai berikut:

$$
\begin{aligned}
& \operatorname{lnupah}_{L}=13,599^{*}+0,0269 \text { perkotaan }+0,1059 \text { kawin }^{*}+0,1814 \text { krt }^{*}+0,2489 \text { SMA }^{*} \\
& +0,5810 \text { pendidikan tinggi }{ }^{*}+0,1533 \text { pelatihan }{ }^{*} \\
& +0,0010 \text { potensi pengalaman kerja }+0,0021 \text { jam kerja }^{*}+0,2324 \text { formal }^{*} \\
& +0,3414 \text { serikat pekerja* }{ }^{*} \text { 0,20079 pertanian* } \\
& +0,3827 \text { industri manufaktur }{ }^{*}+0,5733 \text { TNI dan Polri* } \\
& +0,0948 \text { pekerja kerah putih* }
\end{aligned}
$$

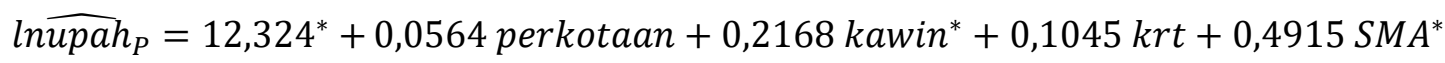

$$
\begin{aligned}
& +0,8795 \text { pendidikan ting gi } i^{*}+0,1648 \text { pelatihan }^{*} \\
& +0,0085 \text { potensi pengalaman kerja }{ }^{*}+0,0037 \text { jam kerja }^{*}+0,4716 \text { formal }^{*} \\
& +0,3680 \text { serikat pekerja* }{ }^{*}+0,5680 \text { pertanian }^{*} \\
& +0,2767 \text { industri manufaktur }{ }^{*}+1,2225 \text { TNI dan Polri* } \\
& +0,2658 \text { pekerja kerah putih* }
\end{aligned}
$$

Tabel 4. Perbandingan Nilai Koefisien Determinasi dan Root MSE antara Regresi OLS dan Regresi Robust MM

No.

Statistik

$$
\text { OLS }
$$

\section{Robust MM} 1

$$
\text { Koefisien Determinasi } \quad \text { Laki-laki }
$$

0,397

0,528

$$
\text { Perempuan }
$$

0,526

2 Root MSE

Laki-laki

0,574

0,575 
Apabila dibandingkan dengan persamaan regresi OLS, koefisien determinasi robust lebih besar dibandingkan OLS, dan root MSE robust tidak berbeda jauh dari root MSE OLS. Hal ini menunjukkan bahwa regresi robust menyediakan hasil estimasi yang lebih baik

Persamaan 23 dan 24 menunjukkan pekerja laki-laki dan perempuan berstatus kawin menerima upah 10,59 persen dan 21,68 persen lebih tinggi dibandingkan pekerja yang tidak kawin. Hasil ini mengonfirmasi konsep marriage premium dalam pasar tenaga kerja (Sukma \& Kadir, 2018). Hasil estimasi juga menunjukkan kedudukan sebagai KRT dalam rumah tangga berpengaruh positif terhadap upah pekerja laki-laki namun tidak berpengaruh terhadap upah perempuan. Drago et al. (Kowalewska \& Vitali, 2019) menyatakan status kepala rumah tangga bagi perempuan merupakan keharusan karena perubahan kondisi, seperti KRT meninggal atau dirumahkan, sehingga perempuan sebagai KRT darurat kesulitan mencari pekerjaan yang sesuai dan layak.

Hasil estimasi upah juga mengonfirmasi pengaruh positif investasi modal manusia terhadap upah pekerja. Sebagaimana yang ditunjukkan pada persamaan 23 dan 24, pendidikan yang lebih tinggi dan pelatihan dapat meningkatkan upah pekerja baik laki-laki ataupun perempuan. Hal ini disebabkan, pendidikan yang lebih tinggi dan pelatihan meningkatkan keterampilan untuk mendukung produktivitas dalam bekerja, sehingga upah yang diperoleh semakin tinggi. Sementara itu, pengalaman kerja hanya berpengaruh terhadap upah pekerja perempuan.

Berdasarkan karakteristik pekerjaan, setiap kenaikan satu jam kerja laki-laki dan perempuan akan meningkatkan upah sebesar 0,21 persen dan 0,37 persen. Sejalan dengan Sukma \& Kadir (2018) keterlibatan pekerja baik laki-laki ataupun perempuan dalam sektor formal dan serikat pekerja akan meningkatkan upah mereka. Hasil estimasi upah laki-laki dan perempuan memperlihatkan upah pekerja sektor pertanian dan sektor industri manufaktur lebih tinggi dibandingkan sektor pelayanan dan jasa. Hasil ini membuktikan pernyataan Grybaite (2006) bahwa upah sektor yang didominasi oleh perempuan (sektor pelayanan dan jasa) lebih rendah dibandingkan sektor yang didominasi laki-laki. Selanjutnya, ditinjau dari jenis pekerjaannya, pekerja laki-laki dan perempuan yang menjabat sebagai TNI dan POLRI atau berkedudukan pada jabatan menengah hingga tinggi (pekerja kerah putih) menerima upah yang lebih tinggi dibandingkan pekerja dengan jabatan rendah (pekerja kerah biru).

\section{Faktor-faktor yang Mempengaruhi Kesenjangan Upah antar Gender}

Hasil dekomposisi Blinder-Oaxaca menunjukkan kesenjangan upah sebesar 0,3659. Artinya rata-rata upah pekerja perempuan 36,59 persen lebih rendah dibandingkan laki-laki. Dari total 36,59 persen tersebut, 17,01 persen poin atau (E/D) 46,49 persen dijelaskan oleh perbedaan karakteristik antara perempuan dan laki-laki (explained). Sementara 19,58 persen poin atau (U/D) 53,51 persen lainnya disebabkan oleh faktor unexplained. Kontribusi faktor unexplained yang lebih tinggi memperkuat indikasi adanya diskriminasi terhadap perempuan. Merujuk pada teori Becker, diskriminasi terhadap perempuan dapat berupa stereotype yang menganggap produktivitas perempuan dalam bekerja rendah, sehingga majikan yang diskriminatif hanya akan mempekerjakan perempuan dengan upah yang rendah. Diskriminasi yang bersumber dari pekerja dapat berupa keengganan untuk dipimpin oleh perempuan sehingga perempuan menghadapi pembatasan karir. Selain itu, pekerja laki-laki yang diskriminatif akan meminta upah premium sebagai kompensasi karena bekerja dengan perempuan (Blau \& Kahn, 2017). 
Tabel 5. Hasil Dekomposisi Blinder-Oaxaca

Estimasi Upah

$\hat{y}_{\text {laki-laki }}$

$\hat{y}_{\text {perempuan }}$

Difference (D)

Perkotaan

Kawin

Kepala Rumah Tangga

SMA Sederajat

Pendidikan Tinggi

Pelatihan

Potensi Pengalaman Kerja

Explained (E)

Unexplained (U)

Jam Kerja

Sektor Formal

Serikat Pekerja

Pertanian

Industri Manufaktur

TNI dan POLRI

Pekerja Kerah Putih

Total
14,9968

0,000

14,6309

0,000

0,3659

0,000

$-0.0020$

0,316

0.0127

0,008

0.1086

0,000

0.0257

0,000

$-0.1249$

0,000

$-0.0014$

0,614

0.0030

0,502

0.0601

0,000

$-0.0101$

0,001

$-0.0091$

0,870

0.0148

0,000

0.1096

0,000

0.0052

0,001

$-0.0305$

0,001

0,1701

0,000

0,1958

0,000

Jika ditinjau lebih detail, ketertinggalan pekerja perempuan dalam karakteristik status perkawinan, status dalam rumah tangga, pendidikan (SMA sederajat), jam kerja, lapangan usaha, dan jenis pekerjaan (TNI dan POLRI) memperlebar kesenjangan upah antar gender. Sebagaimana yang ditunjukkan pada tabel 5 , segregasi pekerjaan yang mengakibatkan rendahnya penyerapan pekerja perempuan dalam sektor industri manufaktur berkontribusi dominan dalam memperlebar kesenjangan upah antar gender, yaitu sebesar 10,96 persen poin. Hasil ini sejalan dengan temuan Sukma \& Kadir (2018) dan Chamberlain (2016). Chamberlain (2016) berargumen bahwa hal ini disebabkan oleh norma sosial yang menuntut perempuan untuk memikul tanggung jawab yang 
tidak proporsional untuk merawat dan mengurus rumah tangga sehingga menekan perempuan untuk melakukan pekerjaan lebih fleksibel dengan gaji yang lebih rendah.

Hasil dekomposisi juga mengonfirmasi peran vital pendidikan dalam menekan kesenjangan upah antar gender. Tabel 5 menunjukkan meluasnya kesempatan perempuan untuk menempuh pendidikan tinggi berkontribusi sebesar 12,49 persen poin dalam mempersempit kesenjangan upah antar gender. Di samping pendidikan, perluasan akses dan kesempatan perempuan untuk terlibat dalam sektor formal dan menduduki jabatan menengah hingga tinggi (kerah putih) terbukti mampu menekan kesenjangan upah antar gender.

\section{KESIMPULAN}

Hasil analisis deskriptif menunjukkan adanya perbedaan karakteristik antara pekerja perempuan dan laki-laki. Secara umum, pekerja perempuan berstatus tidak kawin dan tidak berkedudukan sebagai kepala rumah tangga, sehingga pekerjaan perempuan lazim dianggap sebagai pelengkap atau sekunder. Pekerja perempuan juga tercatat memiliki jam kerja yang lebih pendek dibandingkan laki-laki. Selain itu, penyerapan pekerja perempuan pada sektor industri manufaktur, yaitu sektor yang menyediakan produktivitas dan upah yang lebih baik sangat rendah. Meski tertinggal dalam beberapa karakteristik, pekerja perempuan tercatat lebih baik dalam hal pendidikan, keterlibatan dalam sektor formal, dan, jenis pekerjaan.

Hasil estimasi mendapati bahwa upah pekerja baik laki-laki ataupun perempuan akan meningkat jika: berstatus kawin, menyelesaikan jenjang pendidikan yang lebih tinggi, pernah mengikuti pelatihan kerja, memiliki jam kerja yang lebih panjang, terlibat dalam sektor formal dan serikat pekerja, bekerja pada sektor pertanian atau sektor industri manufaktur, serta menjabat sebagai TNI dan POLRI atau pekerja kerah putih. Perbedaan model upah kedua gender adalah upah pekerja perempuan juga akan meningkat jika memiliki pengalaman kerja yang panjang. Sementara, upah pekerja laki-laki juga akan meningkat jika berkedudukan sebagai kepala rumah tangga.

Selanjutnya, hasil dekomposisi Blinder-Oaxaca menemukan bahwa kesenjangan upah antar gender di Kalimantan Timur pada tahun 2018 adalah sebesar 36,59 persen poin. Dari total kesenjangan upah tersebut, 46,49 persen dijelaskan oleh faktor perbedaan karakteristik antara perempuan dan laki yang diobservasi (explained), sementara 53,51 persen lainnya disebabkan oleh faktor unexplained. Besarnya kontribusi faktor unexplained mengindikasikan bahwa perempuan mengalami perbedaan perlakuan dalam pasar tenaga kerja (diskriminasi).

Dengan demikian, kesenjangan upah antar gender dapat ditekan dengan memperluas akses dan kesempatan perempuan untuk menempuh pendidikan tinggi, terlibat dalam sektor formal, dan menduduki jabatan menengah hingga tinggi (kerah putih). Untuk menghilangkan diskriminasi pengupahan terhadap perempuan, maka perlu diatur regulasi mengenai transparansi pengupahan.

\section{DAFTAR PUSTAKA}

Blau, F. D., \& Kahn, L. M. (2017). The Gender Wage Gap: Extent, Trends, and Explanations. Journal of Economic Literature, 55, 789-865.

Blinder, A. S. (1973). Wage Discrimination: Reduced Form and Structural Estimates. The Journal of Human Resources, 8(4), 436-455.

Chamberlain, A. (2016). Demystifying The Gender Pay Gap:Evidence from Glassdoor Salary Data. In Glassdoor. https://research-content.glassdoor.com/app/uploads/sites/2/2016/03/Glassdoor-GenderPay-Gap-Study.pdf

England, P. (1992). From Status Attainment to Segregation and Devaluation. Contemporary Sociology, 21(5), 643-647.

Francis, D. (2007). Why Do Women Outnumber Men in College? https://www/nber.org/digest/jan07/w12139.html 
Grybaite, V. (2006). Analysis of theoretical approaches to gender pay gap. Journal of Business Economics and Management, 72 ), 85-91. https://doi.org/10.1080/16111699.2006.9636127

Hennigusnia. (2014). Kesenjangan Upah Antar Jender di Indonesia : Glass Ceiling atau Sticky Floor? Kependudukan Indonesia, 9, 83-96.

International Labour Organization. (2016). Laporan Upah Global 2016 / 17 Ketimpangan Upah di Tempat Kerja.

Kowalewska, H., \& Vitali, A. (2019). Work/Family Arrangements across the OECD: Incorporating the FemaleBreadwinner Model. LIS Working Paper Series, 1-35.

Mardiana. (2015). Kesenjangan Penghasilan Antar Gender di Indonesia Tahun 2013 Dengan Metode Dekomposisi Blinder-Oaxaca. Jurnal Aplikasi Statistika Dan Komputasi Statistik, 7, 45-64.

Mincer, J. A. (1974). The Human Capital Earnings Function. Schooling, Experience, and Earnings, I, 83-96.

Oaxaca, R. (1973). Male-Female Wage Differentials in Urban Labour Markets. International Economic Review, 14, 693-709.

Polachek, S. W. (1981). Occupational Self-Selection: A Human Capital Approach to Sex Differences in Occupational Structure. The Review of Economics and Statistics, 63(1), 60-69.

Sukma, W. L., \& Kadir, K. (2018). Decomposition of the Gender Wage Gap in Indonesia: A Picture from Sakernas Data. The Asia-Pacific Research in Social Sciences and Humanities Conference 2018, 1-33.

Susanti, Y., Pratiwi, H., \& H, S. S. (2013). Optimasi Model Regresi Robust Untuk Memprediksi Produksi Kedelai di Indonesia. Seminar Nasional Matematika Dan Pendidikan Matematika, November, 253-262.

Widayanti, D. V., Rachman, N. S. I., \& Mauretya, W. (2013). Pengaruh Pertumbuhan Ekonomi Terhadap Kesenjangan Upah Antar Gender. Proceeding PESAT (Psikologi, Ekonomi, Sastra, Arsitektur \& Teknik Sipil), 5, 303-307. 